\title{
Evaluation of Gum Arabic from Acacia senegal var kerensis and Acacia senegal var senegal as a Stabilizer in Low-fat Yoghurt
}

\author{
Edward Muita Mugo ${ }^{a}$, Symon M. Mahungua ${ }^{a}$ Ben N. Chikamai ${ }^{\mathrm{b}}$, And Johnson K. \\ MWOVE ${ }^{a^{*}}$ \\ ${ }^{\text {a }}$ Department of Dairy and Food science and Technology, Egerton University, P.O. Box 536, Njoro, Kenya \\ ${ }^{\mathrm{b}}$ Kenya Forestry Research Institute P.O. Box 20412-00200 Nairobi, Kenya \\ ${ }^{*}$ Corresponding author \\ mwove@hotmail.com
}

Received: 27 January 2020; Published online: 18 January 2020

\begin{abstract}
Gum arabic is a dried, gummy exudate obtained from the stems and branches of Acacia senegal and Acacia seyal. In Kenya, gum arabic comes from Acacia senegal var kerensis although its exploitation for commercial and industrial application is marginal. Therefore, the aim of this study was to characterize and determine the effect of the gum from A. senegal var kerensis on the quality characteristics of set low-fat yoghurt compared to gum arabic from $A$. senegal var senegal, with a view to increasing its utilization locally. Yoghurt was prepared containing gum arabic at four concentrations $(0.2 \%, 0.4 \%$, $0.6 \%, 0.8 \%$ gum w/v). Results showed that A. senegal var kerensis gum had higher molecular weight and gelling properties compared to A. senegal var senegal gum. In addition, A. senegal var kerensis gum was less susceptible to syneresis and showed a higher absolute viscosity compared to $A$. senegal var senegal gum at all concentration levels. Sensory evaluation revealed that addition of gum arabic significantly improved the body and the texture of the yoghurt. Therefore, A. senegal var kerensis gum is a better yoghurt stabilizer than gum arabic from $A$. senegal var senegal. An optimal gum concentration of $0.6 \%$ of $A$. senegal var kerensis gum in low-fat yoghurt is recommended from the results of this study.
\end{abstract}

Keywords: Gum arabic; Low-Fat Yoghurt; Stabilizer; Syneresis; Gum exudate

\section{Introduction}

Many health organizations consider the level of fat consumption to be too high. A recent World Health Organization (WHO) report recommended that the level of total fat intake should be between $15 \%$ and $30 \%$ of energy, of which saturated fatty acids should account for less than $10 \%$ since fat has been associated with an increased risk of obesity, arteriosclerosis, coronary heart disease, elevated blood pressure, tissue injury diseases associated with lipid oxidation and certain forms of cancer (Kaminarides, Stamou \&
Massouras, 2007). Thus, the goal of the food industry is to respond to consumer demand and to offer an increasing variety of low-fat choices, in which the attributes that consumers desire are not impaired. A reduction in fat content can be achieved by replacing it with several ingredients that provide the functionality of the missing fat. Hydrocolloids and carbohydrate-based fat replacers have been used safely as thickeners and stabilizers especially in dairy products, sauces and dressing formulations. Gum arabic (GA, E-Number 414) is an edible, dried, gummy 
exudate from the stem and branches of $A$. senegal and Acacia seyal that is rich in non-viscous soluble fiber (Williams \& Phillips, 2009). It is defined by the Joint FAO/WHO Expert Committee for Food Additives (JECFA) as a dried exudate obtained from the stems and branches of A. senegal (L.) Willdenow or Acacia seyal (fam. Leguminosae) (FAO, 1999). Physically, it is a pale white to orange-brown solid which breaks with a glassy fracture. Chemically, gum arabic (GA) consists mainly of high molecular weight polysaccharide and their calcium, magnesium and potassium salts, which on hydrolysis yield arabinose, galactose, rhamnose and glucuronic acid (FAO, 1999). The backbone is composed of 1,3 -linked $\beta$-D-galactopyranosyl units. The side chains are composed of two to five 1,3 -linked $\beta$-D-galactopyranosyl units, joined to the main chain by 1, 6-linkages (FAO, 1999). Gum arabic has wide industrial uses as an emulsifier, stabilizer and thickening agent mainly in the food industry. These properties have been exploited for their functionality in food systems including textural attributes and mouth feel. There are two forms available commercially, namely $A$. senegal var senegal and A. senegal var kerensis. Both are acceptable as food additives and conform to the specification now approved by the FAO Joint Expert Committee on Food Additives and the Codex Alimenarius Commission (FAO Food and Nutrition Paper 52 Add.7 1999). A. senegal var senegal gum (standard type), produced in Sudan and other gum-producing regions of Africa, for example Nigeria and Niger, is significantly different from $A$. senegal var karensis gum that is produced in Kenya. The A. senegal var kerensis gum has high specific rotation, high nitrogen content and a high molecular weight compared to the A. senegal var senegal gum (Al-Assaf, Phillips \& Williams, 2005). There are few reports on the research that assessed the qualities of $A$. senegal var kerensis gum for its commercial and industrial application in yoghurt processing.

Yoghurt producers are motivated to market lowfat products with natural ingredients in order to capture a niche market that continues to grow. In addition, producers have added gum arabic as a prebiotic in yoghurt production (Niamah, Al-sahlany \& Al-Manhel, 2016). However, research has shown that reduced fat yoghurt ex- hibits lower tension and firmness than full fat yoghurt. The partial or total removal of fat from yoghurt decreases the overall quality perceived by the consumer (Folkenberg \& Martens, 2003). This is for two main reasons: a change in the texture of the product and a change in the retention of flavor compounds (Nongonierma, Springett, Le Quéré, Cayot \& Voilley, 2006). The change in texture perception results from a modification of the structure of the gels (Kilcast \& Clegg, 2002). Fat globules of homogenized milk are part of the gel network. To modify texture perception, fat substitutes or bodying agents are commonly added (Sandoval-Castilla, LobatoCalleros, Aguirre-Mandujano \& Vernon-Carter, 2004). Some of the additives that have been used include starch and skimmed milk powder. The need to consume low-fat foods has created increased consumer awareness and a dramatic increase in the supply of, and demand for, lowfat foods containing fibers. Gum arabic which is known to possess special emulsifying and stabilizing properties has not been evaluated vis-à-vis low-fat yoghurt stabilization. Thus, the aim of the present study was to determine its effect on the rheological properties of set low-fat yoghurt (EAS, 2006) with a view to increasing its utilization in Kenya.

\section{Materials and Methods}

\subsection{Materials}

Gum arabic from A. senegal var kerensis and $A$. senegal var senegal were obtained from Kenya Forestry Research Institute Laboratories (KEFRI) and used without further purification. Unpasteurized skimmed milk was obtained from a local supplier and used to make low-fat yoghurt the same day.

\subsection{Yoghurt preparation}

The skimmed milk (0.5\% Fat) was heated to 85 ${ }^{\circ} \mathrm{C}$ for $20 \mathrm{~min}$, stabilizer $(0.2 \%, 0.4 \%, 0.6 \%, 0.8 \%$ gum w/v) was added and the mixture heated for a further $10 \mathrm{~min}$ at $85{ }^{\circ} \mathrm{C}$. Yoghurt manufacture was adapted from the standard technique (Kosikowski, 2019). The mixture of milk and ad- 
ded stabilizer was cooled to $45{ }^{\circ} \mathrm{C}$ and a Streptococcus thermophilus and Lactobacillus bulgaricus (direct vat set culture $\left(1 \times 10^{10}\right.$ cfu per gram) (YF-L811, Chr. Hansen, Hamilton, New Zealand) was mixed into the milk and allowed to ferment for $3 \mathrm{~h}$ at $42{ }^{\circ} \mathrm{C}$ in autoclaved glass jars. The warm yoghurt was then kept at $4{ }^{\circ} \mathrm{C}$ for cooling before the various analyses of physicochemical properties of yoghurt were performed after one day. Control yoghurt sample was manufactured following the same standard technique (Kosikowski, 2019) without the addition of a gum arabic.

\subsection{Determination of the physicochemical and molecular characteristics of gum arabic}

The physicochemical properties were obtained and molecular parameters of gum arabic measured using gel permeation chromatography online coupled with multi-angle laser light scattering system (GPC-MALLS). A Superose 6 10/300GL GPC column and a DAWN EOS multi-angle light scattering detector (Wyatt Technology Corporation, USA) were employed in the GPC-MALLS measurements at $25{ }^{\circ} \mathrm{C}$. Aqueous sodium chloride solutions $(0.2 \mathrm{M})$ were used both as a solvent and eluent. This technique is used to determine the molecular distribution of a polymeric system such as hydrogel of hydrocolloids including gum arabic (Al-Assaf et al., 2005; Montoro, de Fátima Medeiros \& Alves, 2014). All chemicals used were of analytical grade and were obtained from BDH Chemicals (BDH Ltd, Poole, England) or Sigma Chemical Co. (St. Louis, Mo, USA) unless specified otherwise.

\subsection{Analysis of physicochemical characteristics of yoghurt containing gum arabic}

\section{Chemical characterization}

The following chemical analyses were carried out on the yoghurt, according to AOAC (2005): moisture $(\mathrm{g} / 100 \mathrm{~g} \mathrm{w} / \mathrm{w})$, ash $(\mathrm{g} / 100 \mathrm{~g} \mathrm{w} / \mathrm{w})$, total solids $(\mathrm{g} / 100 \mathrm{~g} \mathrm{w} / \mathrm{w})$, and fat $(\mathrm{g} / 100 \mathrm{~g}$ $\mathrm{w} / \mathrm{w})$. All analyses were performed in triplicate.

\section{Syneresis of yoghurt}

The susceptibility of yoghurt to syneresis was determined using the method by Keogh and O'kennedy (1998). Centrifuge tubes containing $40 \mathrm{~g}$ of yoghurt were centrifuged at $222000 \mathrm{~g}$ for $10 \mathrm{~min}$ at $4{ }^{\circ} \mathrm{C}$. The clear supernatant was poured off, weighed and expressed as percent weight relative to original weight of yoghurt.

\section{pH value}

The $\mathrm{pH}$ value of the yoghurt samples was measured at the end of the incubation time. Samples were vigorously stirred to break the formed gel and the $\mathrm{pH}$ was obtained using a $\mathrm{pH}$ meter (Orion 4 Star $\mathrm{pH}$. ISE Benchtop, Thermo electric cooperation).

\section{Acidity}

Titratable acidity, expressed as percentage of lactic acid, was determined following FAO (1996) by mixing $10 \mathrm{~g}$ of yogurt with $20 \mathrm{~mL}$ of distilled water and titrating with $0.1 \mathrm{~N} \mathrm{NaOH}$ using phenolphthalein as indicator. Titratable acidity was then calculated as shown in equation 1 :

$$
T A=\frac{\frac{V_{T}}{1000} \cdot N_{N a O H} \cdot 90}{W_{s}} \cdot 100
$$

Where $T A$ is the tritatable acidity, $V_{T}$ is the titer volume, $N_{\mathrm{NaOH}}$ is the normality of $\mathrm{NaOH}$ and $W_{s}$ the weight of the sample.

\section{Viscosity determination}

Yoghurts were mixed with a hand blender at low speed for $15 \mathrm{~s}$. This was to break the gel and to mimic the shaking or stirring by the consumer of the packed yoghurt. The apparent viscosity of the stirred yoghurt was measured with a Brookfield digital rotational viscometer (model DVII+, Brookfield Engineering Laboratories Inc., Middleboro, MA) using a spindle 5 at $100 \mathrm{rpm}$ in $150 \mathrm{~mL}$ of yogurt (Damian, 2013). The spindle rotated in the sample for 1 minute at $10{ }^{\circ} \mathrm{C}$, the indicator stabilized, then the readings were taken. 


\section{Gel strength}

The cylinder penetration test was performed using a Universal Testing Machine (Zwick Z2.5/TN1S, Zwick, Ulm, Germany) equipped with a $500 \mathrm{~N}$ force sensor (Guggisberg, CuthbertSteven, Piccinah, Buetikofer \& Eberhard, 2009). An acrylic glass cylinder ( $\mathrm{h}^{1} / 435 \mathrm{~mm}, \varnothing^{1 / 4} 25.4$ $\mathrm{mm}$ ) was introduced vertically into the $150 \mathrm{~g}$ yoghurt cup with a constant speed of $30 \mathrm{~mm}$ $\min ^{-1}$ for $40 \mathrm{~mm}$. The software TESTXPERT (V10.1) was used to calculate the modulus of deformability (E modulus) using the secant of the values between 0.5 and $1.0 \mathrm{~mm}$ and the force at $35 \mathrm{~mm}(\mathrm{~F}(35 \mathrm{~mm}))$. The penetration force was read directly from the machine. All yoghurts were measured at $10 \pm 1{ }^{\circ} \mathrm{C}$. The mean of two yoghurts from the same batch was calculated.

\section{Rheological determination (Oscillatory test) of yoghurt}

Rheological properties of yoghurt samples were investigated using a controlled stress rheometer (AR-550 TA Instruments, USA) as described by Karazhiyan et al. (2011). About $3.8 \mathrm{~mL}$ of sample were carefully placed in the measuring system and left to rest for about 10 minutes at $5{ }^{\circ} \mathrm{C}$. Measurements were carried out on shear mode at $5{ }^{\circ} \mathrm{C}$, using a cone and plate geometry. A shear rate sweep test was used with the shear rate ranging from $10^{-2}$ to $20^{-1} \mathrm{~s}$. A frequency sweep test was also performed (with the frequency ranging from 1 to $10 \mathrm{~Hz}$ at a maximum strain of 4.06E-03, and amplitude of 1.42E-04). Because gels are viscoelastic materials, dynamic rheological tests to evaluate properties of gel systems are well suited for studying the characteristics of gels as well as gelation and melting (Walstra, Walstra, Wouters \& Geurts, 2005). From dynamic rheological tests in the linear viscoelastic range, the storage modulus, G', and the loss modulus G", can be obtained. The G' value is a measure of the deformation energy stored in the sample during the shear process, representing the elastic behavior of a sample. In contrast, the G" value is a measure of the deformation energy used up in the sample during the shear and lost to the sample afterwards, representing the viscous behavior of a sample (Mezger, 2002). If the value
$\mathrm{G}^{\prime}$ is much greater than the G" value, the material will behave more like a solid; that is, the deformations will be essentially elastic to recoverable. However, if G" is much greater than G', the energy used to deform the material is dissipated viscously and the material behavior is liquid-like. These parameters represent the mouth feel from a consumer perspective.

\section{Sensory evaluation of yoghurt containing gum arabic}

Descriptive sensory analysis was performed following Meilgaard, Carr and Civille (1999) under normal light. The samples were placed in clear plastic cups. A panel consisting of seven semitrained panelists was used for the evaluation. Three training sessions were held prior to testing using low-fat and full-fat yoghurt. In these sessions, the panelists were trained in the products and descriptors were chosen based on consensus among panelists, using low-fat products available on the market to cover a range of consistencies. A total of seven descriptors were used for the assessment of product appearance, texture, taste and overall acceptability. Test samples, identified by a three-digit code, were presented to the panelists in a randomized order immediately after being removed from the fridge $\left(4^{\circ} \mathrm{C}\right)$. Testing was conducted on duplicate samples, and each panelist was asked to assess them for each attribute on a nine-point scale.

\subsection{Statistical analysis}

The experiment was repeated twice (Trial 1 and Trial 2) in triplicate each time. Statistical analysis was performed using JMP Software. Oneway analysis of variance (ANOVA) was done and mean comparison achieved using the Duncan's multiple range test at $95 \%$ confidence interval 
(Sall, Stephens, Lehman \& Loring, 2017).

\section{Results and Discussions}

\subsection{Physicochemical and molecular characteristics of gum arabic}

The results of the physicochemical and molecular testing of gum arabic are shown in table 1 . The moisture content was $14.5 \%$ and $13.0 \%$ while the ash content was $3.6 \%$ and $3.2 \%$ for A. senegal var kerensis and $A$. senegal var senegal gum, respectively. The protein content of gum arabic from variety kerensis was higher than that of variety Senegal. In addition, both intrinsic and absolute viscosities were higher in the gum arabic from variety kerensis. This may be explained by the high molecular weight reported for variety kerensis compared to variety senegal. These results agree with Al-Assaf et al. (2005). According to these researchers, one of the major differences of the A. senegal var kerensis gum from Kenya is that it has high specific rotation, high nitrogen content and a high molecular weight compared to the A. senegal var senegal gum.

\subsection{Moisture loss}

The results of moisture loss in yoghurt containing gum arabic are shown in Tables 2 and 3. Moisture content was significantly reduced with addition of gum arabic from both varieties. Similar results were reported when gum arabic was added in kobe, a traditional fermented milk from Sudan (Hamad, Sulieman \& Salih, 2013). In addition, Niamah et al. (2016) reported a slight decrease in moisture content of yoghurt when gum arabic was added up to a level of $1 \%$. The moisture loss of the yoghurt stabilized with $A$. senegal var kerensis gum was significantly different $(P$ $<0.05)$ compared to the yoghurt stabilized with $A$. senegal var senegal gum at all levels of gum concentration. Gum arabic from A. senegal var kerensis has been shown to retain higher moisture content in food products (Mwove, A. Gogo, N. Chikamai, Omwamba \& M. Mahungu, 2016, 2018). This can be explained by the high protein content of $A$. senegal var kerensis gum which is much higher than that of $A$. senegal var senegal gum. Senthil, Ravi, Bhat and Seethalakshmi (2002), reported that protein has a high waterbinding capacity.

The analysis of variance results of the physicochemical analysis of all the experimental yoghurts (1 day after preparation) are shown in Tables 2 and 3. The low-fat yoghurt stabilized with $0.8 \%$ A. senegal var kerensis gum had the highest total solids content while the control low-fat yoghurt had the lowest. Total solid increased as the level of gum arabic concentration increased. Mehanna, Ibrahim and El-Nawasany (2013), Obodoechi (2015) and Mahjoub (2016) reported an increase in total solids when gum arabic was added as a stabilizer in low-fat yoghurt. The ash content between yoghurt stabilized and the control was significantly different $(P<0.05)$. Similar results were observed when gum arabic was used in making Robe, a traditionally fermented milk product in Sudan (Hamad et al., 2013). In this research, addition of gum arabic at $5 \%, 7.5 \%$ and $10 \%$ significantly increased the ash content of the resulting product. It is evident that gum arabic did not affect the fat content. However, research involving higher levels of gum arabic, $1-4 \%$ have been found to reduce the fat content of yoghurt (Meso et al., 2013).

\section{$3.3 \mathrm{pH}$ value and acidity}

As shown in Tables 2 and 3, the $\mathrm{pH}$ and acidity values for the entire yoghurt samples did not show any significant difference from the control. The $\mathrm{pH}$ ranged from 4.32 to 4.41 and titratable acidity ranged from 1.12 to $1.38 \%$ lactic acid. No significant differences were noted between samples at different levels of both stabilizers. Results from this study indicate that the addition of gum arabic at different concentrations does not affect the $\mathrm{pH}$ or the titratable acidity of the low-fat yoghurts. Similar observations were reported when inulin, a plant extract was used (Guven, Yasar, Karaca \& Hayaloglu, 2005) as a fat replacer. Other studies also reported that the $\mathrm{pH}$ of plain set yoghurt was not influenced by the incorporation of six different dietary fibers (Bayarri, Chulia \& Costell, 2010). 
Gum arabic as a stabilizer in low-fat yoghurt |SI115

Table 1: Physico-chemical characteristics of $A$. senegal var kerensis gum and A. senegal var senegal gum

\begin{tabular}{llll}
\hline Characteristic & A. senegal var kerensis & A. senegal var senegal & JECFA standards \\
\hline Moisture content & $14.5 \%$ & $13.0 \%$ & $<15 \%$ \\
Ash content & $3.6 \%$ & $3.2 \%$ & $<4 \%$ \\
Nitrogen content & 0.68 & 0.38 & - \\
Protein content (N x 6.63) & 3.42 & 2.01 & - \\
pH -1\% & 4.54 & 4.31 & - \\
Viscosity- Intrinsic viscosity & $27 \mathrm{ml} / \mathrm{g}$ & $17.5 \mathrm{ml} / \mathrm{g}$ & - \\
Viscosity - Absolute viscosity & $170 \mathrm{mPas}$ & $71.6 \mathrm{mPas}$ & -26 to -34 \\
Optical rotation & -34.5 & -28 & - \\
Gel determination & Moderate gel & Light gel & - \\
Tannin Content & - & - & \\
Equivalent weight & 906 & 1150 & \\
Molecular weight & $1.19 \mathrm{X} 10^{6}$ & $5.99 \times 10^{5}$ & \\
\hline
\end{tabular}

Table 2: Physico-chemical properties of yoghurt stabilized with A. senegal var kerensis gum

\begin{tabular}{|c|c|c|c|c|c|c|c|c|c|c|}
\hline & \multicolumn{5}{|l|}{ Trial $1^{*}$} & \multicolumn{5}{|l|}{ Trial $2^{*}$} \\
\hline & Control & 0.2 & 0.4 & 0.6 & 0.8 & Control & 0.2 & 0.4 & 0.6 & 0.8 \\
\hline Moisture loss (\%) & $88.2 \mathrm{a}$ & $84.6 \mathrm{~b}$ & $84.7 \mathrm{~b}$ & $84.0 \mathrm{~b}$ & $84.5 \mathrm{~b}$ & $87.6 \mathrm{a}$ & $82.7 \mathrm{~b}$ & $82.4 \mathrm{~b}$ & $84.8 \mathrm{ab}$ & $82.5 \mathrm{~b}$ \\
\hline Ash content $(\mathrm{g} / 100 \mathrm{~g})$ & $0.89 \mathrm{~d}$ & $2.14 \mathrm{c}$ & $2.22 \mathrm{bc}$ & $2.30 \mathrm{~b}$ & $2.41 \mathrm{a}$ & $0.82 \mathrm{e}$ & $2.14 \mathrm{~d}$ & $2.23 \mathrm{c}$ & $2.34 \mathrm{~b}$ & $2.43 \mathrm{a}$ \\
\hline Fat content $(\mathrm{g} / 100 \mathrm{~g})$ & $0.50 \mathrm{~b}$ & $0.53 \mathrm{a}$ & $0.51 \mathrm{ab}$ & $0.50 \mathrm{~b}$ & $0.51 \mathrm{ab}$ & $0.51 \mathrm{a}$ & $0.50 \mathrm{a}$ & $0.54 \mathrm{a}$ & $0.53 \mathrm{a}$ & $0.53 \mathrm{a}$ \\
\hline Total Solid (g/100g) & $10.30 \mathrm{e}$ & $11.68 \mathrm{~d}$ & $12.48 \mathrm{c}$ & $14.87 \mathrm{~b}$ & $18.21 \mathrm{a}$ & $10.50 \mathrm{e}$ & $11.35 \mathrm{~d}$ & $12.56 \mathrm{c}$ & $14.69 \mathrm{~b}$ & $17.67 \mathrm{a}$ \\
\hline $\mathrm{pH}$ value & $4.37 \mathrm{a}$ & $4.33 \mathrm{a}$ & $4.36 \mathrm{a}$ & $4.37 \mathrm{a}$ & $4.34 \mathrm{a}$ & $4.38 \mathrm{a}$ & $4.35 \mathrm{a}$ & $4.33 \mathrm{a}$ & $4.34 \mathrm{a}$ & $4.35 \mathrm{a}$ \\
\hline Acidity & $1.16 \mathrm{~b}$ & $1.22 \mathrm{a}$ & $1.22 \mathrm{a}$ & $1.70 \mathrm{~b}$ & $1.23 \mathrm{a}$ & $1.16 \mathrm{a}$ & $1.12 \mathrm{a}$ & $1.15 \mathrm{a}$ & $1.14 \mathrm{a}$ & $1.15 \mathrm{a}$ \\
\hline Syneresis & $68.0 \mathrm{a}$ & $54.0 \mathrm{~b}$ & $50.0 \mathrm{c}$ & $45.2 \mathrm{~d}$ & $42.0 \mathrm{e}$ & $70.0 \mathrm{a}$ & $54.7 \mathrm{~b}$ & $51.2 \mathrm{c}$ & $48.2 \mathrm{~d}$ & $44.1 \mathrm{e}$ \\
\hline Viscosity & $870.0 \mathrm{e}$ & $1351.6 \mathrm{~d}$ & $1381.7 \mathrm{c}$ & $1455 \mathrm{~b}$ & $1526.7 \mathrm{a}$ & $890.0 \mathrm{e}$ & $1288.3 \mathrm{~d}$ & $1337.7 \mathrm{c}$ & $1394.3 \mathrm{~b}$ & $1476.7 \mathrm{a}$ \\
\hline Gel strength & $125.5 \mathrm{e}$ & $144.8 \mathrm{~d}$ & $154.1 \mathrm{c}$ & $167.1 \mathrm{~b}$ & $187.7 \mathrm{a}$ & $120.0 \mathrm{e}$ & $131.9 \mathrm{~d}$ & $139.3 \mathrm{c}$ & $145.2 \mathrm{~b}$ & $153.4 \mathrm{a}$ \\
\hline
\end{tabular}

a - e Means followed by the same letters are not significantly different according to Duncan's Multiple Range Test at P $\leq 0.05$

* Means separation carried out separately for each trial.

Table 3: Physico-chemical properties of yoghurt stabilized with A. senegal var kerensis gum

\begin{tabular}{|c|c|c|c|c|c|c|c|c|c|c|}
\hline & \multicolumn{5}{|l|}{ Trial $1 *$} & \multicolumn{5}{|l|}{ Trial $2^{*}$} \\
\hline & Control & 0.2 & 0.4 & 0.6 & 0.8 & Control & 0.2 & 0.4 & 0.6 & 0.8 \\
\hline Moisture loss (\% MC) & $88.20 \mathrm{a}$ & $87.60 \mathrm{~b}$ & $86.32 \mathrm{~b}$ & $87.45 b$ & $87.02 b$ & $87.45 \mathrm{a}$ & $86.68 \mathrm{~b}$ & $85.42 \mathrm{~b}$ & $85.45 b$ & $85.67 \mathrm{~b}$ \\
\hline Ash content (g/100g) & $0.89 \mathrm{e}$ & $2.15 \mathrm{~d}$ & $2.24 \mathrm{c}$ & $2.29 \mathrm{~b}$ & $2.38 \mathrm{a}$ & $0.82 \mathrm{~d}$ & $1.18 \mathrm{c}$ & $1.28 \mathrm{~b}$ & $1.32 \mathrm{~b}$ & $1.43 \mathrm{a}$ \\
\hline Fat content (g/100g) & $0.50 \mathrm{a}$ & $0.54 \mathrm{a}$ & $0.54 \mathrm{a}$ & $0.50 \mathrm{a}$ & $0.50 \mathrm{a}$ & $0.50 \mathrm{a}$ & $0.52 \mathrm{a}$ & $0.55 \mathrm{a}$ & $0.52 \mathrm{a}$ & $0.52 \mathrm{a}$ \\
\hline Total Solid (g/100g) & $10.3 \mathrm{~d}$ & $10.2 \mathrm{~d}$ & $11.7 \mathrm{c}$ & $13.5 \mathrm{~b}$ & $16.4 \mathrm{a}$ & $10.5 \mathrm{~d}$ & $10.4 \mathrm{~d}$ & $12.0 \mathrm{c}$ & $13.9 \mathrm{~b}$ & $17.6 \mathrm{a}$ \\
\hline $\mathrm{pH}$ value & $4.37 \mathrm{a}$ & $4.32 \mathrm{ab}$ & $4.32 \mathrm{ab}$ & $4.33 \mathrm{ab}$ & $4.30 \mathrm{~b}$ & $4.35 \mathrm{a}$ & $4.39 \mathrm{a}$ & $4.41 \mathrm{a}$ & $4.37 \mathrm{a}$ & $4.40 \mathrm{a}$ \\
\hline Acidity & $1.16 \mathrm{a}$ & $1.15 \mathrm{a}$ & $1.14 \mathrm{a}$ & $1.17 \mathrm{a}$ & $1.38 \mathrm{a}$ & $1.12 \mathrm{a}$ & $1.16 \mathrm{a}$ & $1.16 \mathrm{a}$ & $1.17 \mathrm{a}$ & $1.34 \mathrm{a}$ \\
\hline Syneresis & $68.0 \mathrm{a}$ & $56.3 \mathrm{~b}$ & $52.3 \mathrm{c}$ & $49.7 \mathrm{~cd}$ & $47.0 \mathrm{~d}$ & $70.0 \mathrm{a}$ & $56.3 \mathrm{~b}$ & $52.3 \mathrm{bc}$ & $49.0 \mathrm{~cd}$ & $45.3 \mathrm{~d}$ \\
\hline Viscosity & $870.0 \mathrm{e}$ & $1176.7 \mathrm{~d}$ & $1208.3 \mathrm{c}$ & $1231.7 \mathrm{~b}$ & $1258.3 \mathrm{a}$ & $890.0 \mathrm{~d}$ & $1175.0 \mathrm{c}$ & $1210.0 \mathrm{~b}$ & $1228.3 \mathrm{ab}$ & $1251.7 \mathrm{a}$ \\
\hline Gel strength & $125.5 \mathrm{e}$ & $127.1 \mathrm{~d}$ & $129.6 \mathrm{c}$ & $133.2 \mathrm{~b}$ & $135.7 \mathrm{a}$ & $120.0 \mathrm{e}$ & $126.1 \mathrm{~d}$ & $129.0 \mathrm{c}$ & $131.5 b$ & $135.0 \mathrm{a}$ \\
\hline
\end{tabular}

a - e Means followed by the same letters are not significantly different according to Duncan's Multiple Range Test at P $\leq 0.05$

*Means separation carried out separately for each trial. 


\subsection{Syneresis index}

The amount of syneresis in the control was significantly greater $(P<0.05)$ than the amount of syneresis in the treatments with both gum stabilizers used, as shown in Tables 2 and 3. The most important causes for syneresis in fermented products include the use of high temperatures for incubation, low solids content or inadequate storage temperatures (Lucey, 2001). Syneresis is for the most part due to a rearrangement of the network, leading to an increase in the number of particle-particle junctions. The network then tends to shrink, leading to whey separation (appearance of whey on the gel surface of set yoghurt). Although total solids were kept constant for both stabilizers, the yoghurt made from A. senegal var kerensis gum was less susceptible to syneresis and showed a significantly $(P<0.05)$ lower syneresis index compared to $A$. senegal var senegal gum at all concentration levels. The syneresis index for the gum-stabilized yoghurt decreased as the concentration level of the gum increased. This low syneresis in the A. senegal var kerensis gum-stabilized yoghurt can be attributed to the improved water holding capacity by the $A$. senegal var kerensis gum (Mwove et al., 2016, 2018). Enrichment of dry matter and / or of protein content are common means of avoiding whey separation in yoghurt (Tamime \& Robinson, 1999). It has been shown that there is a relationship between the microstructure of yoghurt and firmness and susceptibility to syneresis. Yoghurts which have a denser structure and lower porosity exhibit more water retention capacity (Puvanenthiran, Williams \& Augustin, 2002). It was reported (Staff, 1998) that low-fat yoghurts tend to have a higher degree of syneresis than high-fat yoghurts and this is the reason why stabilizers are added to low-fat yoghurt. The current work shows that the gum arabic from $A$. senegal var kerensis forms a better firm microstructure due to its high molecular weight than $A$. senegal var senegal gum as shown in reduction of syneresis. The stabilizers make the yoghurt less susceptible to rearrangements within its network, and consequently less susceptible to shrinkage and serum (whey) expulsion (Oh, Anema, Wong, Pinder \& Hemar, 2007). Yoghurt is usually prepared from ho- mogenized milk to improve stability. This process coats the increased surface of fat globules with casein, enabling the fat globules to participate as a copolymer with casein to strengthen the gel network and reduce syneresis (Keogh \& O'kennedy, 1998). Therefore, it can be concluded that the gum arabic helped in forming protein-coated gum arabic spheres, which reinforced the gel structure by their association with casein micelles of the protein network.

\subsection{Viscosity}

The current result shows that there was a significant difference $(P<0.05)$ between the control and the yoghurt with added gum arabic (Tables 2 and 3). Significant differences $(P<0.05)$ were noted between samples from gum arabic $A$. senegal var kerensis at different levels of the gum concentration with viscosity increasing with increase in gum amounts for both. The higher absolute viscosity reported for low-fat yoghurt stabilized with $A$. senegal var kerensis gum than $A$. senegal var senegal gum is attributed to the higher molecular weight and gelling properties of the $A$. senegal var kerensis gum as compared to A. senegal var senegal gum. While studying the effect of guar gum and arabic gum on the physicochemical, sensory and flow behavior characteristics of frozen yoghurt, Rezaei, Khomeiri, Kashaninejad and Aalami (2011) found that increasing gum arabic in yoghurt increased the viscosity of resulting product. In addition, similar results were reported by Obodoechi (2015). Since yoghurt is usually prepared from homogenized milk to improve stability, this process coats the increased surface of fat globules with casein, enabling the fat globules to participate as a copolymer with casein to strengthen the gel network (Keogh \& O'kennedy, 1998), hence increased viscosity. It has been previously reported that the protein network of low-fat yoghurt was less dense, more open, and with more void spaces than that of full-fat yoghurt. This is due to the smaller, fused casein micelle aggregates, probably due to lower number of fat globules acting as linking protein agents (Sandoval-Castilla et al., 2004). In the present study, the increase in viscosity suggests that the gum arabic participates as co- 
polymer with casein. The A. senegal var kerensis gum is better at enhancing viscosity compared to A. senegal var senegal gum. The casein micelles in the low-fat yoghurt containing fat replacers form networks with differing structures depending on the chemical nature and functional properties of the fat replacers (Lucey, 2001).

\subsection{Gel strength/ Firmness}

The gel strength of gum arabic stabilized low-fat yoghurt was evaluated following a back-extrusion test performed on a universal testing machine (Houze, Cases, Colas \& Cayot, 2005). The results for the samples containing gum arabic from $A$. senegal var kerensis and $A$. senegal var senegal gum are presented in Tables 2 and 3 . The yoghurt samples stabilized with $A$. senegal var kerensis gum and $A$. senegal var senegal gum were significantly different $(P<0.05)$ from each other in terms of their gel firmness and also at different concentration level of the stabilizer. The gel strength of the yoghurt increased as the gum amount increased with the highest value record at the highest stabilizer concentration of $0.8 \%$ for both gums. This may be due to the increased levels of total solids, high molecular weight and gelling properties of gum arabic from Acacia senagal var kerensis, and also potential thermodynamic compatibility between casein and the gum arabic from $A$. senegal var kerensis. A high intrinsic viscosity or hydrodynamic molecular volume of the polysaccharide leads to smaller occupied volumes, which contribute to less exclusion of the polysaccharide in mixtures (Keogh \& O'kennedy, 1998). This explains the difference in gel strength between A. senegal var kerensis gum and $A$. senegal var senegal gum. Thus, the aggregation of milk proteins, especially casein micelles decreases and consequently, phase separation is reduced. The potential electrostatic bonding between the hydroxyl groups of gum arabic and the positively charged regions on $k$-casein could have played a role in increasing the gel strength of the yoghurt (Guven et al., 2005). Similar results were reported on incorporation of either beta-glucan or inulin in yoghurt (Guven et al., 2005). The formulation resulted in an increase in product firmness and consistency in comparison with the control samples. The highest firmness and consistency of beta-glucan products was obtained from formulations containing a $2.5 \%$ addition level. The texture and the rheological results are in agreement with trends observed for yoghurt syneresis and increased gel strength (G' and firmness).

\subsection{Rheological properties (Oscillatory test) of low-fat yoghurt}

In the present study, storage $\left(\mathrm{G}^{\prime}\right)$ and loss $\left(\mathrm{G}^{\prime \prime}\right)$ modulus values were determined and were found to be dependent on frequency at all concentrations studied (Figures 1- 4). Increasing the gum arabic concentration for both stabilizers up to $0.8 \%$ increased the value of both G" and G'. This is due to the increase in carboxylic crosslinking between the stabilizer and the casein micelles which play a dominant role in increasing the G'value of acid gels made from heated milk (Guven et al., 2005). Yoghurt enriched with $A$. senegal var kerensis gum at different gum arabic concentrations showed higher G' and G" values than control yoghurt. The same results were recorded for the A. senegal var senegal gum (Table 4). These values increased as the level of the stabilizer increased. Research has shown that heating milk to above $70{ }^{\circ} \mathrm{C}$ at natural $\mathrm{pH}$ predominantly promotes the unfolding of whey proteins and their complex formation with casein micelles involving $\beta$-casein (Guven et al., 2005). Gum arabic associates with casein micelles via the formation of intermolecular carboxylic bonds found in the AGP fraction. The binding of gum arabic to the micelle surface induces the formation of bridges between the casein particles and induces a network dominated by casein-AGP fraction interaction at $\mathrm{pH}$ 4.6. Gum arabic-arabinogalactan (AGP) fraction aggregates that associate with casein micelles help to crosslink casein particles and increase the number and strength of bonds between protein particles. This explains the rise of both G' and G" as the concentration of the gum is increased as shown in Table 4. The high G' and G" recorded for A. senegal var kerensis compared to $A$. senegal var senegal is due to the high molecular weight associated to the 
SI118 | Mugo et al.

Table 4: Physico-chemical properties of yoghurt stabilized with A. senegal var kerensis gum

\begin{tabular}{lllllll}
\hline & & Control & $0.2 \%$ & $0.4 \%$ & $0.6 \%$ & $0.8 \%$ \\
\hline \multirow{2}{*}{ A. senegal var kerensis } & G' & $99.92 \mathrm{e}$ & $145.92 \mathrm{~d}$ & $191.92 \mathrm{c}$ & $232.92 \mathrm{~b}$ & $262.92 \mathrm{a}$ \\
& G' & $25.27 \mathrm{e}$ & $26.27 \mathrm{~d}$ & $27.57 \mathrm{c}$ & $28.57 \mathrm{~b}$ & $29.57 \mathrm{a}$ \\
A. senegal var senegal & G' & $99.92 \mathrm{e}$ & $139.79 \mathrm{~d}$ & $179.87 \mathrm{c}$ & $221.80 \mathrm{~b}$ & $250.90 \mathrm{a}$ \\
& G' & $25.27 \mathrm{e}$ & $24.65 \mathrm{~cd}$ & $25.87 \mathrm{bc}$ & $26.98 \mathrm{ab}$ & $28.24 \mathrm{a}$ \\
\hline
\end{tabular}

a - e Means followed by the same letters are not significantly different according to

Duncan's Multiple Range Test at $\mathrm{P} \leq 0.05$

*Means separation carried out separately for each trial.

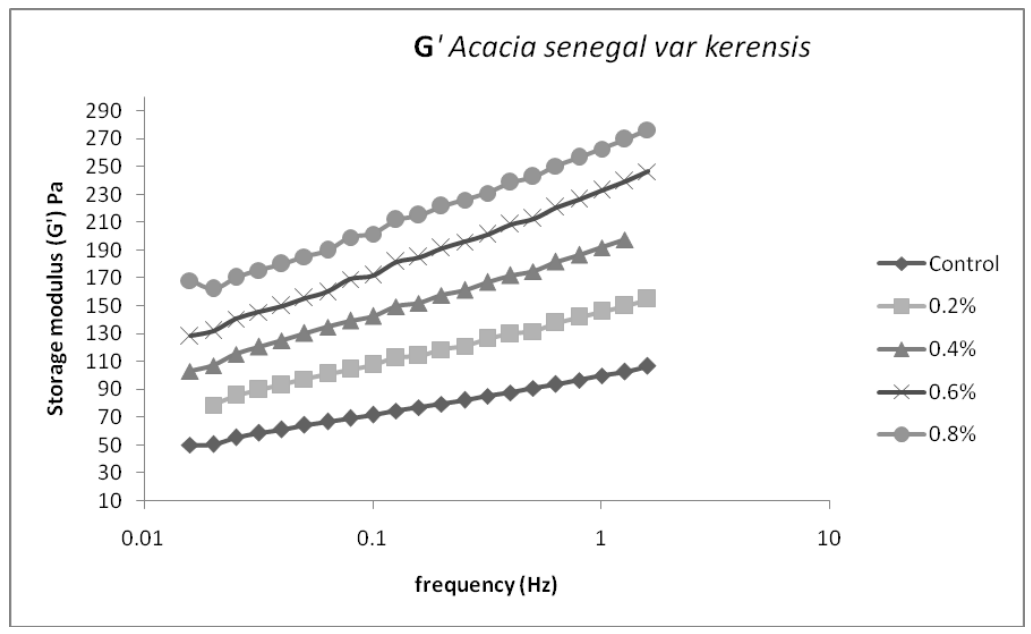

Figure 1: G'A. senegal var kerensis stabilized for low-fat yoghurt

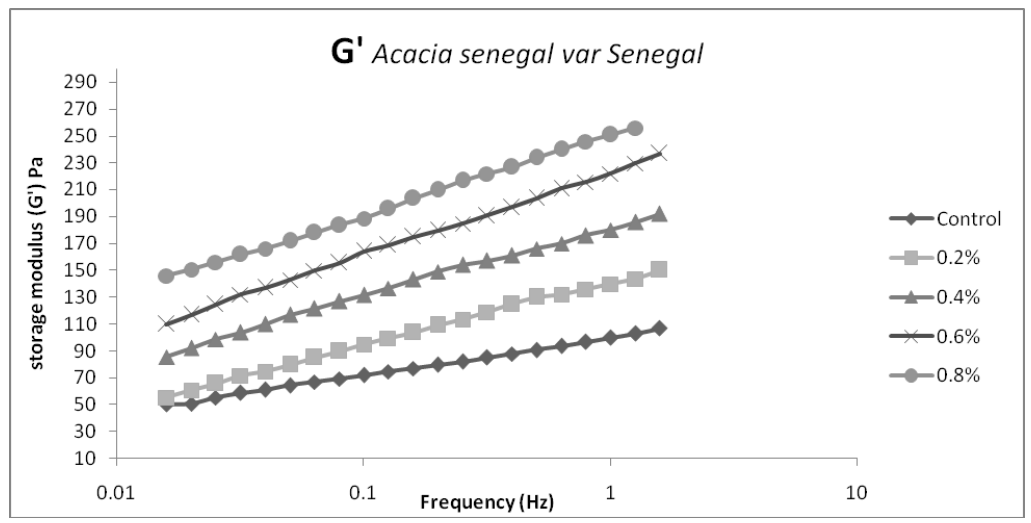

Figure 2: G' A. senegal var senegal stabilized for low-fat yoghurt

IJFS | January 2020 | Volume 9 | pages SI110-SI124 
Gum arabic as a stabilizer in low-fat yoghurt |SI119

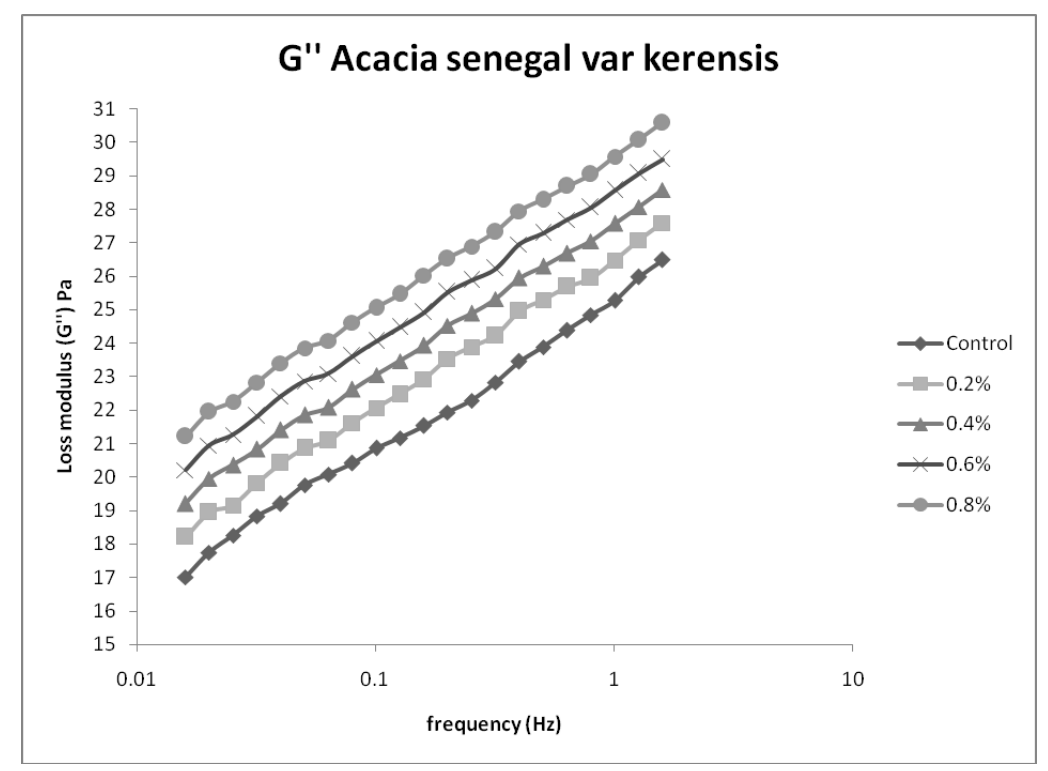

Figure 3: G" A. senegal var kerensis stabilized for low-fat yoghurt

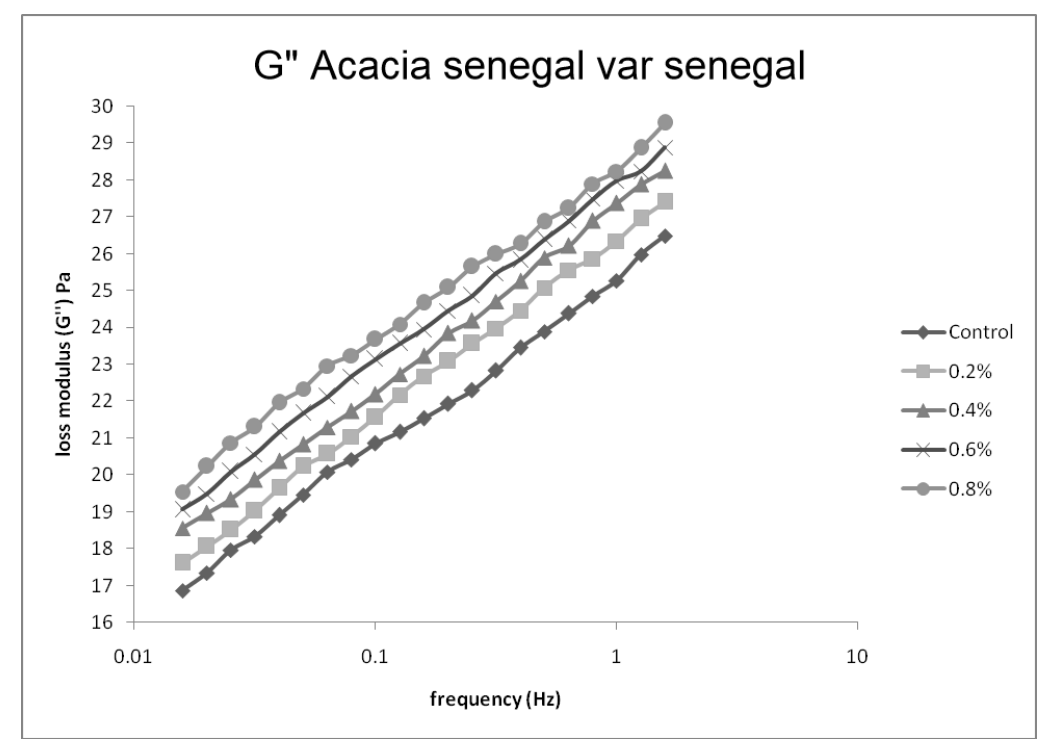

Figure 4: G" A. senegal var senegal stabilized for low-fat yoghurt 
AGP content and the gelling property of the $A$. senegal var kerensis gum. High levels of hydrocolloids have been reported to increase whey protein self-aggregation (Mezger, 2002) and formation of a protein matrix with dominant whey protein aggregates. Most hydrocolloids are generally carboxylated or sulphated. Gum arabic carries carboxylic groups (Mezger, 2002) and is also an anionic polysaccharide, which can adsorb onto casein micelles during acidification. An adsorbing polymer, depending on its concentration, can lead to a colloidal system through the whole series of no influence - bridging - polymeric stabilization - depletion - destabilization (Syrbe, Bauer \& Klostermeyer, 1998). If the amount of polymer is not large enough to completely cover the protein, a polysaccharide may be adsorbed onto more than one protein surface, thereby bridging two or more protein particles. However, flocculation becomes more and more effective up to about half of the saturation surface coverage (Mezger, 2002).

\subsection{Sensory evaluation}

Texture properties can often be assessed with instruments, but this is insufficient in characterizing the product. Many consumers use the sensory properties of foods to judge freshness and quality of a product (Kealy, 2006). Sensory properties including flavor, mouth feel and color can be evaluated by trained or untrained panelists (Kuenzel, Zandstra, El Deredy, Blanchette \& Thomas, 2011). Consumer testing could provide the most meaningful and reliable information on the textural quality and acceptability of yoghurt (Jaworska, Szulinska, Wilk \& Anuszewska, 2005). In the present study, panel testing procedures were carried out. Sensory analyses on appearance, texture, taste, body and overall acceptance of the $A$. senegal gum stabilized low- fat yoghurt as well as control samples were evaluated by 7 trained panelists using a 9point hedonic scale (Kuenzel et al., 2011). Panelists were asked to score sample attributes from extremely like (9) to extremely dislike (1). Thus the highest numbers represented more desirable, and the lowest less desirable traits. The analysis of variance results are presented in Table 5 for A. senegal var kerensis and A. senegal var senegal. The control skim milk yoghurt had the lowest scores in all aspects except in appearance and taste. Both gum arabic from $A$. senegal var kerensis and $A$. senegal var senegal had no effect on the appearance/ color of the low-fat yoghurt as the gum content was increased. Gum arabic from the initial characterization was found to be tasteless and odorless thus it did not cause significant difference in the low-fat yoghurt. Similar results were reported by Akhtar and Dickinson (2007) and Yadav, Igartuburu, Yan and Nothnagel (2007) where gum arabic did not have any effect on taste and appearance of the beverage prepared.

Addition of gum arabic to skim milk yoghurt improved the texture and body of the yoghurt and the acceptability rating changed significantly $(P$ $<0.05)$. Similar results were found when gum arabic was added to frozen yoghurt showing an increase in acceptability with increase in gum level up to a level of $0.5 \%$ (Rezaei et al., 2011). In addition, Moeenfard and Tehrani (2008) and Rezaei et al. (2011) reported an improvement in texture when stabilizers are used. However, Mahjoub (2016) reported a decrease in color, flavor, taste and overall acceptability when gum arabic and baobab were added up to $0.3 \%$ in yoghurt. The texture of the low-fat yoghurt increased as the level of concentration of gum arabic (both gums) increased. The results show that the panel preferred the yoghurt stabilized with $A$. senegal var kerensis gum to $A$. senegal var senegal gum. This was due to the high molecular weight and gelling property of A. senegal var kerensis gum leading to a better mouth feel. These results suggest that gel strength correlated with consumer acceptance. These findings are similar to earlier results suggesting a positive correlation between acceptance and gel strength of yoghurt (Frost \& Janhoj, 2007).

The body of the yoghurt increased as the concentration of the gum arabic was increased (Table 5 ). These results correlate with the results from gel strength and rheological properties which showed that the G', and G" was highest in the $0.8 \%$ concentration level of gum arabic. Samples containing 0.4 and $0.6 \%$ A. senegal var kerensis were also regarded as smooth. The low-fat yogurt containing $0.8 \%$ of $A$. senegal var keren- 
Gum arabic as a stabilizer in low-fat yoghurt |SI121

Table 5: Sensory analysis results for low- fat yoghurt stabilized with A. senegal var kerensis and $A$. senegal var senegal gum

\begin{tabular}{|c|c|c|c|c|c|c|c|c|c|c|c|}
\hline & & $\begin{array}{l}\text { Trial } 1 \\
\text { Control }\end{array}$ & 0.2 & 0.4 & 0.6 & 0.8 & $\begin{array}{l}\text { Trial } 2 \\
\text { Control }\end{array}$ & 0.2 & 0.4 & 0.6 & 0.8 \\
\hline \multirow{3}{*}{ A. senegal } & Appearance & $7.5 \mathrm{~b}$ & $7.2 \mathrm{~b}$ & $7.2 \mathrm{~b}$ & $8.4 \mathrm{a}$ & $8.4 \mathrm{a}$ & $7.4 \mathrm{~b}$ & $7.2 \mathrm{~b}$ & $7.3 \mathrm{~b}$ & $8.3 \mathrm{a}$ & $8.1 \mathrm{a}$ \\
\hline & Texture & $3.8 \mathrm{~d}$ & $5.5 \mathrm{c}$ & $7.0 \mathrm{~b}$ & $8.0 \mathrm{ab}$ & $8.8 \mathrm{a}$ & $3.8 \mathrm{~d}$ & $5.5 \mathrm{c}$ & $6.7 \mathrm{~b}$ & $8.2 \mathrm{a}$ & $8.7 \mathrm{a}$ \\
\hline & Taste & $8.9 \mathrm{a}$ & $7.0 \mathrm{~b}$ & $6.0 \mathrm{c}$ & $7.0 \mathrm{~b}$ & $5.8 \mathrm{~d}$ & $8.9 \mathrm{a}$ & $7.0 \mathrm{~b}$ & $6.0 \mathrm{c}$ & $7.0 \mathrm{~b}$ & $5.8 \mathrm{a}$ \\
\hline \multirow{2}{*}{ var kerensis } & Body & $3.8 \mathrm{~d}$ & $5.5 \mathrm{c}$ & $6.6 \mathrm{~b}$ & $8.2 \mathrm{a}$ & $8.6 \mathrm{a}$ & $3.8 \mathrm{~d}$ & $5.5 \mathrm{c}$ & $7.0 \mathrm{~b}$ & $8.0 \mathrm{ab}$ & $8.8 \mathrm{a}$ \\
\hline & Overall acceptance & $4.8 \mathrm{c}$ & $6.0 \mathrm{bc}$ & $6.6 \mathrm{~b}$ & $8.3 \mathrm{a}$ & $6.6 \mathrm{~b}$ & $4.7 \mathrm{c}$ & $5.8 \mathrm{bc}$ & $6.8 \mathrm{~b}$ & $8.0 \mathrm{a}$ & $6.5 \mathrm{~b}$ \\
\hline \multirow{3}{*}{ A. senegal } & Appearance & $7.5 \mathrm{~b}$ & $6.6 \mathrm{~b}$ & $7.2 \mathrm{~b}$ & $8.4 \mathrm{a}$ & $8.4 \mathrm{a}$ & $7.4 \mathrm{~b}$ & $7.2 \mathrm{~b}$ & $7.3 \mathrm{~b}$ & $8.3 \mathrm{a}$ & $8.1 \mathrm{a}$ \\
\hline & Texture & $3.8 \mathrm{~d}$ & $5.0 \mathrm{c}$ & $6.5 \mathrm{~b}$ & $7.0 \mathrm{ab}$ & $7.4 \mathrm{a}$ & $3.8 \mathrm{~d}$ & $4.8 \mathrm{c}$ & $5.2 \mathrm{~b}$ & $6.8 \mathrm{a}$ & $7.5 \mathrm{a}$ \\
\hline & Taste & $8.9 \mathrm{a}$ & $6.8 \mathrm{~b}$ & $6.0 \mathrm{c}$ & $7.0 \mathrm{~b}$ & $5.6 \mathrm{~d}$ & $8.9 \mathrm{a}$ & $7.0 \mathrm{~b}$ & $6.2 \mathrm{c}$ & $6.8 \mathrm{~b}$ & $5.6 \mathrm{a}$ \\
\hline \multirow{2}{*}{ var senegal } & Body & $3.8 \mathrm{~d}$ & $4.0 \mathrm{c}$ & $5.5 \mathrm{~b}$ & $6.0 \mathrm{a}$ & $7.0 \mathrm{a}$ & $3.8 \mathrm{~d}$ & $3.8 \mathrm{c}$ & $5.6 \mathrm{~b}$ & $6.4 \mathrm{ab}$ & $7.2 \mathrm{a}$ \\
\hline & Overall acceptance & $4.8 \mathrm{c}$ & $5.0 \mathrm{bc}$ & $6.0 \mathrm{~b}$ & $7.0 \mathrm{a}$ & $6.0 \mathrm{~b}$ & $4.7 \mathrm{c}$ & $5.2 \mathrm{bc}$ & $5.8 \mathrm{~b}$ & $6.5 \mathrm{a}$ & $6.0 \mathrm{~b}$ \\
\hline
\end{tabular}

a - e Means followed by the same letters are not significantly different according to Duncan's Multiple Range Test at $\mathrm{P} \leq 0.05$

*Means separation carried out separately for each trial.

sis was said to have a slimy texture and some panelist described it as too smooth, which was not profound. Some authors have indicated that smoothness is a highly desirable sensory characteristic in food emulsions such as dairy products (Bayarri, Carbonell, Barrios \& Costell, 2011). Smoothness of dairy products decreases due to increased average size of the fat globules by decreasing the average distance between them and increasing the variation in their size for full-fat yoghurt. Additionally, smoothness can be related to creaminess and thickness (which depends on the viscosity). Both proteins and polysaccharides contribute to the structural and textural properties of yoghurt. The expert panel indicated a preference for yoghurts containing $0.6 \%$ A. senegal var kerensis after one day of storage.

\section{Conclusion}

Gum arabic from A. senegal var kerensis can be used as a stabilizer in low-fat yoghurt formulations and this increases consumer acceptability. The present study demonstrates that stabilization of low-fat yoghurt with A. senegal var kerensis improves the textural quality of set-style yoghurts. The study showed that $A$. senegal var kerensis gum imparts better rheological properties to low-fat yoghurt when used as a stabilizer compared to A. senegal var senegal. Gum ar- abic from A. senegal var kerensis can be used in low-fat yoghurt to prevent serum separation and to adjust the viscosity. When used at a sufficient level, stabilizers reduced serum separation and increased apparent viscosity. A. senegal var kerensis gum addition was found to be a better yoghurt stabilizer than gum arabic from $A$. senegal var senegal. The optimal gum concentration in low-fat yoghurt recommended from the results of this study is $0.6 \%$ of $A$. senegal var kerensis gum.

\section{Acknowledgements}

We would like to thank Phillips hydrocolloids Research Centre, Kenya Forestry Research Institute and Food science and technology department, Egerton University for allowing us to use their research facility. The director of Kenya Gum and Resins Limited, Mr. Mutuma Marangu for funding the research in North Wales United Kingdom.

\section{References}

Akhtar, M. \& Dickinson, E. (2007). Whey protein-maltodextrin conjugates as emulsifying agents: An alternative to gum arabic. Food Hydrocolloids, 21 (4), 607-616. doi:10. 1016/j.foodhyd.2005.07.014 
AOAC. (2005). Official methods of analysis (16th ed.), association of official analytical chemists, arlington, va.

Al-Assaf, S., Phillips, G. O. \& Williams, P. A. (2005). Studies on acacia exudate gums. part i: The molecular weight of acacia senegal gum exudate. Food Hydrocolloids, 19(4), 647-660. doi:10.1016/j . foodhyd . 2004.09.002

Bayarri, S., Carbonell, I., Barrios, E. X. \& Costell, E. (2011). Impact of sensory differences on consumer acceptability of yoghurt and yoghurt-like products. International Dairy Journal, 21(2), 111-118. doi:10 . 1016/j.idairyj.2010.09.002

Bayarri, S., Chulia, I. \& Costell, E. (2010). Comparing lambda-carrageenan and an inulin blend as fat replacers in carboxymethyl cellulose dairy desserts. rheological and sensory aspects. Food Hydrocolloids, 24(6-7), 578-587. doi:10.1016/j. foodhyd.2010.02. 004

Damian, C. (2013). Influence of dietary fiber addition on some properties of yoghurt. Analele Universitatii" Ovidius" ConstantaSeria Chimie, 24(1), 17-20.

EAS. (2006). Yoghurt. Specification. East African Standards. First Edition 2006, EAS 33:2006, ICS 67.100. Retrieved from https://law.resource.org/pub/eac/ibr/eas. 33.2006.pdf

FAO. (1996). Manuals of food quality control: 8. food analysis: Quality, adulteration, and tests of identity (vol. 2). Food \& Agriculture Organization, Rome, Italy.

FAO. (1999). Compendium of food additive specifications addendum 7 . food and nutrition paper, no. 52. add. 7. Joint FAO/WHO Expert Committee on Food Additives 53rd Session Held in Rome, 1-10 June 1999. Rome: FAO.

Folkenberg, D. M. \& Martens, M. (2003). Sensory properties of low fat yoghurts. part a: Effect of fat content, fermentation culture and addition of non-fat dry milk on the sensory properties of plain yoghurts. Milchwissenschaft-milk Science International, 58(1-2), 48-51.

Frost, M. B. \& Janhoj, T. (2007). Understanding creaminess. International Dairy Journal,
17(11, SI), 1298-1311. doi:10.1016 / j . idairyj.2007.02.007

Guggisberg, D., Cuthbert-Steven, J., Piccinah, P., Buetikofer, U. \& Eberhard, P. (2009). Rheological, microstructural and sensory characterization of low-fat and whole milk set yoghurt as influenced by inulin addition. International Dairy Journal, 19(2), 107-115. doi:10.1016/j.idairyj.2008.07.009

Guven, M., Yasar, K., Karaca, O. B. \& Hayaloglu, A. A. (2005). The effect of inulin as a fat replacer on the quality of set-type low-fat yogurt manufacture. International Journal of Dairy Technology, 58(3), 180184. doi:10.1111/j.1471-0307.2005.00210.x

Hamad, H. E., Sulieman, A. M. E. \& Salih, Z. A. (2013). Quality aspects of the sudanese fermented milk (robe) supplemented with gum arabic powder. Discourse $J$ Agric Food Sci, 1(1), 8-13.

Houze, G., Cases, E., Colas, B. \& Cayot, P. (2005). Viscoelastic properties of acid milk gel as affected by fat nature at low level. International Dairy Journal, 15(10), 10061016. doi:10.1016/j.idairyj.2004.09.007

Jaworska, M., Szulinska, Z., Wilk, M. \& Anuszewska, E. (2005). Separation of synthetic food colourants in the mixed micellar system application to pharmaceutical analysis. Journal of Chromatography A, 1081(1), 42-47. doi:10.1016/j.chroma. 2005.03 .045

Kaminarides, S., Stamou, P. \& Massouras, T. (2007). Comparison of the characteristics of set type yoghurt made from ovine milk of different fat content. International Journal of Food Science and Technology, 42(9), 1019-1028. doi:10.1111/j.1365-2621.2006. 01320.x

Karazhiyan, H., Razavi, S. M. A., Phillips, G. O., Fang, Y., Al-Assaf, S. \& Nishinari, K. (2011). Physicochemical aspects of hydrocolloid extract from the seeds of Lepidium sativum. International Journal of Food Science and Technology, 46(5), 1066-1072. doi:10.1111/j.1365-2621.2011.02583.x

Kealy, T. (2006). Application of liquid and solid rheological technologies to the textural characterisation of semi-solid foods. 
Gum arabic as a stabilizer in low-fat yoghurt $\mid$ SI123

Food Research International, 39(3), 265276. doi:10.1016/j.foodres.2005.07.016

Keogh, M. K. \& O'kennedy, B. T. (1998). Rheology of stirred yogurt as affected by added milk fat, protein and hydrocolloids. Journal of Food Science, 63(1), 108-112.

Kilcast, D. \& Clegg, S. (2002). Sensory perception of creaminess and its relationship with food structure. Food Quality and Preference, 13(7-8), 609-623. doi:10.1016/S09503293(02)00074-5

Kosikowski, F. V. (2019). Cheese and fermented milk foods / frank kosikowski. Serbiula (sistema Librum 2.0).

Kuenzel, J., Zandstra, E. H., El Deredy, W., Blanchette, I. \& Thomas, A. (2011). Expecting yoghurt drinks to taste sweet or pleasant increases liking. Appetite, 56(1), 122-127. doi:10.1016/j.appet.2010.12.009

Lucey, J. A. (2001). The relationship between rheological parameters and whey separation in milk gels. Food Hydrocolloids, 15 (46), 603-608. doi:10.1016/S0268-005X(01) 00043-1

Mahjoub, S. M. M. A. (2016). Effect of baobab (Adansonia digitata) pulp fruit, gum arabic and storage period on physicochemical and sensory characteristics of set yoghurt (Doctoral dissertation, University of Khartoum). Retrieved from http: / / khartoumspace . uofk . edu / handle / $123456789 / 20140$

Mehanna, N. M., Ibrahim, E. M. \& El-Nawasany, L. I. (2013). Impact of some hydrocolloids on the physical characteristics and quality of non-fat yoghurt. Egyptian Journal of Dairy Science, 41(2), 163-170.

Meilgaard, M. C., Carr, B. T. \& Civille, G. V. (1999). Sensory evaluation techniques. CRC press.

Meso, R. O. E. et al. (2013). Evaluation of mango fruit yogurt produced from camel milk supplemented with gum arabic (Doctoral dissertation, Sudan University of Science \& Technology). Retrieved from http : / / repository.sustech.edu/handle/123456789/ 3762

Mezger, T. G. (2002). The rheology handbook: For users of rotational and oscillatory rheo- meters. Vincentz Verlag, Hanover, Germany, 299.

Moeenfard, M. \& Tehrani, M. (2008). Effect of some stabilizers on the physicochemical and sensory properties of ice cream type frozen yogurt. American-Eurasian Journal Agricaltural and Environmenal Science, 4.

Montoro, S. R., de Fátima Medeiros, S. \& Alves, G. M. (2014). Chapter 10 - nanostructured hydrogels. In S. Thomas, R. Shanks \& S. Chandrasekharakurup (Eds.), Nanostructured polymer blends (pp. 325-355). doi:10. 1016/B978-1-4557-3159-6.00010-9

Mwove, J., A. Gogo, L., N. Chikamai, B., Omwamba, M. \& M. Mahungu, S. (2016). Preparation and quality evaluation of extended beef rounds containing gum arabic from acacia senegal var. kerensis. Food and Nutrition Sciences, 07, 977-988. doi:10. 4236/fns. 2016.711096

Mwove, J., A. Gogo, L., N. Chikamai, B., Omwamba, M. \& M. Mahungu, S. (2018). Principal component analysis of physicochemical and sensory characteristics of beef rounds extended with gum arabic from acacia senegal var. kerensis. Food Science \&3 Nutrition, 6. doi:10.1002/fsn3.576

Niamah, A., Al-sahlany, S. \& Al-Manhel, A. (2016). Gum arabic uses as prebiotic in yogurt production and study effects on physical, chemical properties and survivability of probiotic bacteria during cold storage. World Applied Sciences Journal, 34, 1190-1196. doi:10.5829/idosi.wasj.2016.34. 9.184

Nongonierma, A., Springett, M., Le Quéré, J. L., Cayot, P. \& Voilley, A. (2006). Flavour release at gas/matrix interfaces of stirred yoghurt models. International Dairy Journal, 102-110. doi:10.1016/j . idairyj.2005.01.010

Obodoechi, C. M. (2015). Influence of stabilizers on the fermentation rate and nutritive value of set yoghurt (Doctoral dissertation). Retrieved from http://dspace.unn. edu . ng : 8080 / jspui / handle / 123456789 / 1361

Oh, H. E., Anema, S. G., Wong, M., Pinder, D. N. \& Hemar, Y. (2007). Effect of potato starch addition on the acid gelation of milk. 
International Dairy Journal, 17(7), 808815. doi:10.1016/j.idairyj.2006.09.013

Puvanenthiran, A., Williams, R. P. W. \& Augustin, M. A. (2002). Structure and viscoelastic properties of set yoghurt with altered casein to whey protein ratios. International Dairy Journal, 12(4), 383-391. doi:10.1016/S0958-6946(02)00033-X

Rezaei, R., Khomeiri, M., Kashaninejad, M. \& Aalami, M. (2011). Effects of guar gum and arabic gum on the physicochemical, sensory and flow behaviour characteristics of frozen yoghurt. International Journal of Dairy Technology, 64(4), 563-568. doi:10. 1111/j.1471-0307.2011.00705.x

Sall, J., Stephens, M. L., Lehman, A. \& Loring, S. (2017). JMP start statistics: a guide to statistics and data analysis using JMP. Sas Institute.

Sandoval-Castilla, O., Lobato-Calleros, C., Aguirre-Mandujano, E. \& Vernon-Carter, E. J. (2004). Microstructure and texture of yogurt as influenced by fat replacers. International Dairy Journal, 14(2), 151159. doi:10.1016/S0958-6946(03)00166-3

Senthil, A., Ravi, R., Bhat, K. K. \& Seethalakshmi, M. K. (2002). Studies on the quality of fried snacks based on blends of wheat flour and soya flour. Food Quality and Preference, 13(5), 267-273. doi:10.1016/S09503293(02)00023-X

Staff, M. C. (1998). Cultured milk and fresh cheeses. The technology of dairy products, 123-144.

Syrbe, A., Bauer, W. J. \& Klostermeyer, N. (1998). Polymer science concepts in dairy systems-an overview of milk protein and food hydrocolloid interaction. International Dairy Journal, 8(3), 179-193. doi:10.1016/S0958-6946(98)00041-7

Tamime, A. Y. \& Robinson, R. K. (1999). Yoghurt-science and technology, 2nd ed. International Journal of Dairy Technology, 52, 148-148. doi:10.1111/j.1471-0307.1999. tb02857.x

Walstra, P., Walstra, P., Wouters, J. T. M. \& Geurts, T. J. (2005). Dairy science and technology (B. Raton, Ed.). doi:10.1201/ 9781420028010
Williams, P. \& Phillips, G. (2009). 11 - gum arabic. In G. Phillips \& P. Williams (Eds.), Handbook of hydrocolloids (second edition) (Second Edition, pp. 252-273). Woodhead Publishing Series in Food Science, Technology and Nutrition. doi:10.1533/ 9781845695873.252

Yadav, M. P., Igartuburu, J. M., Yan, Y. \& Nothnagel, E. A. (2007). Chemical investigation of the structural basis of the emulsifying activity of gum arabic. Food Hydrocolloids, 21(2), 297-308. doi:10.1016/j . foodhyd. 2006.05.001 